\title{
ANALISIS KELAYAKAN USAHATANI CABAI MERAH DI LAHAN GAMBUT KOTA PALANGKA RAYA KALIMANTAN TENGAH (The Feasibility Of Red Chili Farming In Peatlands Of Palangka Raya In Central Kalimantan)
}

\author{
Astri, A. ${ }^{1)}$ \\ ${ }^{1)}$ Balai Pengkajian Teknologi Pertanian Kalimantan Tengah \\ Jalan G.Obos KM 5 Palangka Raya \\ HP : 08125929831 Email : astrianto24@ymail.com \\ Diterima : 29/5/2017_ Disetujui : 29/9/2017
}

\begin{abstract}
Red chili becomes one of commodity contributor to inflation in Central Kalimantan. This is because the price of chili that continues to rise and tend to be unstable, and its supply is still dependent from outside Central Kalimantan.Red chili cultivation has not been developed in peatlands. Palangka Raya has peatland potential for the development of red chilicultivation. The assessment aims to get the feasibility of red chili farming in peatlands of Palangka Raya in Central Kalimantan. The assessment conducted in the PetukKatimpun Villages, District Jekan Raya in June to November 2014, with the planting on the farmer's land cooperators 0.25 hectares. The technology cultivation adopted from Indonesian Vegetable Research Institute (Balitsa) which has been modified. Pillar varieties used are favored by the market because of its shape. Giving fertilizer used manure $20 \mathrm{t} / \mathrm{ha}$, NPK 16:16:16 $1 \mathrm{t} / \mathrm{ha}$, dolomite $2 \mathrm{t} / \mathrm{ha}$, limestone $1 \mathrm{t} / \mathrm{ha}$, calcium boron 14 liter/ha. The assessment results obtained production of red chili $16,743 \mathrm{t} / \mathrm{ha}$. The value of $\mathrm{R} / \mathrm{C}$ ratio of 5.89 and $\mathrm{B} / \mathrm{C} 4.89$ so red chili farming in the peatlands feasible to develop and profitably.
\end{abstract}

Keywords: Red Chili, Peatlands, Feasibility Analysis

\begin{abstract}
ABSTRAK
Cabai merah menjadi salah satu komoditas penyumbang inflasi di Kalimantan Tengah. Hal ini dikarenakan harga cabai yang terus naik, cenderung tidak stabil serta pasokan yang masih tergantung dari luar Kalimantan Tengah. Budidaya cabai merah juga belum banyak dikembangkan di lahan gambut. Kota Palangka Raya mempunyai lahan gambut yang potensial untuk pengembangan budidaya cabai merah. Pengkajian ini bertujuan untuk mendapatkan hasil kelayakan usaha tani cabai merah di lahan gambut Kota Palangka Raya Kalimantan Tengah. Pengkajian ini dilaksanakan di Desa Petuk Katimpun Kecamatan Jekan Raya pada Juni sampai Nopember 2014 dengan melakukan penanaman dilahan petani kooperator seluas 0,25 ha. Teknologi budidaya diadopsi dari Balai Penelitian Tanaman Sayuran (Balitsa) yang telah dimodifikasi. Varietas yang digunakan adalah Pilar karena bentuknya disukai oleh pasar. Pemberian pemupukan menggunakan pupuk kandang 20 t/ha, NPK $16: 16: 161 \mathrm{t} / \mathrm{ha}$, dolomite $2 \mathrm{t} / \mathrm{ha}$, kapur bangunan $1 \mathrm{t} / \mathrm{ha}$, calcium boron 14 liter/ha. Hasil pengkajian didapatkan produksi cabaimerah 16,743 t/ha. Nilai R/C ratio sebesar 5.89 dan B/C 4.89 sehingga usaha tani cabaimerah di lahan gambut layak untuk dikembangkan dan menguntungkan.
\end{abstract}

Kata Kunci: Cabai Merah, Lahan Gambut, Analisis Kelayakan 


\section{PENDAHULUAN}

Cabai merah merupakan salah satu kebutuhan pokok masyarakat sebagai penyedap makanan dan belum tergantikan oleh produk olahan sejenis seperti bubuk cabai. Berdasarkan data statistik 2012, produksi cabai merah di Kalimantan Tengah adalah 7,467 ton dengan tingkat produktivitas sebesar 1,76 ton/ha. Nilai produktivitas ini relatif rendah bila dibandingkan dengan ratarata produktivitas hasil panen cabai besar di provinsi lain di pulau Kalimantan yang ratarata mencapai 3,8 ton/ha atau 7,98 ton/ha untuk nasional. Informasi dari data Survei Sosial Nasional diketahui juga bahwa tingkat konsumsi cabai besar masyarakat Indonesia selama tahun 2009-2013 adalah 14,24 ons/tahun atau setara dengan $0,4 \mathrm{~kg} /$ tahun. Sedangkan jumlah masyarakat Kalimantan Tengah pada tahun 2012 adalah 2,28 juta orang maka kebutuhan masyarakat Kalimantan Tengah untuk cabai besar adalah 912 ton. Dengan demikian masih terdapat kekurangan sebesar 165 ton yang harus didatangkan dari luar Kalimantan Tengah.

Kekurangan produksi itulah yang merupakan peluang pasar masyarakat Kalimantan Tengah yang dapat digarap. Bila kekurangan ini dikonversikan ke areal tanam maka Kalimantan Tengah didasarkan pada angka produksi rata-rata dari Badan Pusat Statistik yang besarnya 1,76 ton/ha masih memerlukan lahan tanam sekurang-kurangnya 290 ha.

Berkurangnya lahan yang produktif untuk budidaya cabai mengharuskan untuk dilakukan budidaya dilahan yang marjinal. Berdasarkan data monografi Tahun 2012 Kota Palangka Raya dengan luas wilayah 2,678.51 Km2 (267,851 Ha) memiliki karakteristik lahan yang didominasi oleh jenis tanah marjinal berupa tanah pasir kuarsa dan gambut dengan luas masing-masing 117,606 $\mathrm{Ha}$ dan 103,638 Ha. Dari luasan lahan marjinal tersebut diatas tercatat $\pm 1,265$ Ha yang telah dimanfaatkan sebagai lahan usaha tani tanaman palawija dan hortikultura.
Lahan gambut pada umumnya tanahnya bereaksi masam sampai sangat masam ( $\mathrm{pH}$ rendah), KTK tinggi, ketersediaan hara kurang tersedia akan menyulitkan serapan unsur hara yang diperlukan tanaman. Oleh karena itu, didalam pengelolaan tanah gambut selain perlu penyehatan tanahnya, juga perlu pemberian pupuk makro dan mikro serta harus disesuaikan dengan kebutuhan tanaman dan tanahnya (Suryanto, 1994).

Rendahnya produksi cabai merah di Kalimantan Tengah disebabkan oleh beberapa faktor antara lain: (a)adanya serangan organisme pengganggu tumbuhan yang dapat menurunkan kualitas dan kuantitas tanaman cabai merah, (b) tanah yang marjinal sehinggapertumbuhan tanaman kurang optimal, (c) rendahnya hara yang tersedia bagi tanaman, (d) kurangnya pengetahuan petani tentang teknik budidaya yang tepat dan belum diketahuinya jenis pupuk buatan yang tepat dan mampu meningkatkan produksi cabai merah (Dinas Pertanian dan Peternakan Provinsi Kalimantan Tengah,2010).

Masih banyak anggapan akibat rendahnya produksi cabai, petani tidak mendapatkan keuntungan. Hal ini disebabkan biaya produksi lebih tinggi dari hasil yang diperoleh. Selain teknis budidaya, pemilihan waktu yang tepat untuk bertanam cabai juga merupakan faktor yang ikut memberikan kontribusi besar dalam melakukan usaha tani cabai. Berdasarkan hal tersebut, pengkajian ini bertujuan untuk melakukan analisis financial tentang kelayakan usahatani cabai merah di lahan gambut Kota Palangka Raya Kalimantan Tengah.

\section{BAHAN DAN METODE}

Lokasi Pengkajian ditentukan secara sengaja (purposive) yaitu berada di Desa Petuk Katimpun Kecamatan Jekan Raya Provinsi Kalimantan Tengah dengan pertimbangan di desa ini akan dibuka hutan dengan vegetasi lahan gambut seluas 200 ha. Kajian ini menggunakan data primer dengan penanaman langsung di lahan gambut yang baru dibuka pada lahan Rudi Kuswanto, petani 
kooperator seluas 0,25 ha. Penanaman dilaksanakan pada bulan Juli 2014. Sedangkan data sekunder sebagai data dukung berasal dari pustaka seperti BPS Kalimantan Tengah, Dinas Pertanian dan Peternakan Provinsi Kalimantan Tengah dan instansi lainnya.

Teknologi budidaya diadopsi dari

Balai Penelitian Tanaman Sayuran (Balitsa) yang telah dimodifikasi. Varietas yang digunakan adalah Pilar karena bentuknya disukai oleh pasar. Pemberian pemupukan menggunakan pupuk kandang 20 t/ha, NPK 16:16:16 $1 \mathrm{t} / \mathrm{ha}$, dolomite $2 \mathrm{t} / \mathrm{ha}$, kapur bangunan $1 \mathrm{t} / \mathrm{ha}$, kalcium boron $14 \mathrm{l} / \mathrm{ha}$. Peralatan yang digunakan adalah cangkul, sprayer, sabit/parang serta gembor. Semai dilaksanakan pada tanggal 19 Juni 2014 dan pindah tanam ke lahan pada tanggal 30 Juli 2014. Panen perdana dilaksanakan pada 11 Oktober 2014 dan berakhir pada 12 Nopember 2014 dengan waktu panen selama 10 kali petik. Pengamatan dilakukan terhadap hasil tanaman cabai merah yang meliputi hasil produksi (ton/ha). Diperoleh dengan cara mengkonversikan berat buah pertanaman contoh ke dalam ton/ha.

Analisis kelayakan finansial digunakan untuk menghitung kelayakan usahatani cabai merah dilahan gambut dengan menggunakan analisis $\mathrm{R} / \mathrm{C}$ ratio (Revenue Cost Ratio) dan B/C ratio. Soekartawi (1995) mengemukakan bahwa analisis Revenue Cost Ratio merupakan analisis yang melihat perbandingan antara penerimaan dan pengeluaran.

Secara matematis model kelayakan

dapat diformulasikan sebagai berikut:

$\mathrm{R} / \mathrm{C}$ ratio

$\mathrm{R}=$ Penerimaan atau nilai produksi

$\mathrm{C}=$ Total biaya yang dikeluarkan.

$\mathrm{B} / \mathrm{C}$

$\mathrm{B}=$ Keuntungan

$\mathrm{C}=$ Total biaya yang dikeluarkan

Apabila $\mathrm{R} / \mathrm{C}=1$, berarti usaha tani yang dilakukan tidak untung dan tidak pula rugi atau impas, selanjutnya bila $\mathrm{R} / \mathrm{C}<1$, menunjukkan bahwa usaha tersebut tidak layak diusahakan dan jika $\mathrm{R} / \mathrm{C}>1$, maka usaha tani tersebut layak untuk diusahakan (Soekartawi, 2002).

\section{HASIL DAN PEMBAHASAN}

\section{Gambaran Umum Wilayah}

Kalimantan Tengah mempunyai luas wilayah $153,564.5 \mathrm{~km}^{2}$ yang beribukota di Palangka Raya. Sayuran masih didatangkan dari sentra produksi sayuran di Kecamatan Sebangau maupaun Bukit Batu. Jekan Raya sebagai salah satu kecamatan yang paling dekat dengan pusat kota berpotensi untuk menjadi sentra penghasil sayuran. Namun kendala yang dihadapi adalah jenis tanah berupa gambut. Menurut data dari Dinas Pertanian dan Peternakan Provinsi Kalimantan Tengah, Provinsi Kalimantan Tengah merupakan wilayah yang mempunyai lahan gambut terluas ketiga di Indonesia, yaitu 2,934,660 hektar dan baru dimanfaatkan untuk lahan pertanian seluas 1,320,000 hektar yang berarti 842,000 hektar masih merupakan lahan tidur. Untuk itu perlu dilakukan pengkajian dan penelitian tentang komoditas yang cocok dan menguntungkan untuk dikembangkan dilahan gambut, salah satunya adalah cabai merah.

Ciri yang menonjol dari gambut di Kalimantan Tengah adalah kehomogenannya, artinya gambut tersebut tergolong dalam tingkat kesuburan rendah, kapasitas tukar kation (KTK) tinggi dengan kejenuhan basa (KB) rendah yang menyebabkan basa seperti $\mathrm{K}^{+}, \mathrm{Ca}^{++}$, dan $\mathrm{Mg}^{++}$sukar tersedia bagi tanaman. Selain itu reaksi tanah tergolong sangat masam dan tingkat pelapukan bahan organik yang rendah sehingga unsur hara mikro seperti $\mathrm{Cu}, \mathrm{Zn}$, dan $\mathrm{Mn}$ menjadi sukar tersedia.

Sifat hidrologis gambut sangat ditentukan oleh kematangan gambut. Menurut tingkat kematangannya gambut dibedakan dalam bahan organik fibrik, hemik, dan saprik. Fibrik merupakan tanah gambut yang tingkat pelapukkannya terendah dan $2 / 3$ volume masih terisi serat, hemik memiliki tingkat kematangan sedang dan kandungan seratnya 
$1 / 3-2 / 3$ volume, sedangkan saprik merupakan gambut yang memiliki kematangan sempurna (paling lapuk) dan memiliki $1 / 3$ volume.

Rendahnya produktivitas lahan gambut karena banyaknya kendala yang ditemukan pada lahan tersebut. Dari segi fisik gambut memiliki bobot volume rendah sehingga jumlah unsur hara dan air yang dapat disediakan per satuan volume gambut jauh lebih rendah dibanding tanah mineral. Dari sisi biologi rendahnya jumlah dan aktivitas mikroorganisme heterotrof menjadikan laju pematangan gambut lambat padahal tingkat kematangan gambut merupakan salah satu penentu kesuburan gambut. Kendala dari segi kimia antara lain gambut bereaksi masam hingga sangat masam, KTK tinggi dengan KB rendah. Kondisi ini tidak menunjang tersedianya unsur hara yang memadai bagi kebutuhan tanaman terutama unsur hara seperti $\mathrm{K}, \mathrm{Mg}$ dan $\mathrm{Ca}$. (Halim $d k k$, 1988).

\section{Varietas Pilar}

Tanaman cabai Pilar direkomendasi untuk ditanam di dataran tinggi, tahan penyakit BW, Phytopthora Crk, dan tahan iklim panas. Umur panen 110-115 hari sesudah tanam. Potensi hasil 16-25 ton/ha. Buahnya berwarna merah cerah dengan bentuk agak lonjong panjang dengan diameter $\pm 1.5 \mathrm{~cm}$ dengan panjang sekitar 12-15 cm.(Benih Produksi Cap Panah Merah Indonesia).

Tanaman cabai merah pada dasarnya akan lebih sesuai bila ditanam di daerah kering dan berhawa panas walaupun daerah tersebut merupakan daerah pegunungan. Tanaman cabai membutuhkan penyinaran optimal antara 10-12 jam dengan suhu antara $25^{\circ} \mathrm{C}-30^{\circ} \mathrm{C}$. Suhu siang dibawah $25^{\circ} \mathrm{C}$ akan menghambat pembentukan dan perkembangan bunga, sebaliknya jika suhu berada diatas $30^{\circ}$ $\mathrm{C}$ bunga akan menjadi kering dan gugur. Ketinggian optimal antara 400-600 m dpl dengan kemiringan tidak lebih dari $30^{\circ}$, kelembapan sekitar 60-80 \%, pH yang cocok untuk tanaman cabai 5-6. Cabai tidak tahan terhadap kekeringan sehingga membutuhkan air yang cukup banyak. Saat kritis tanaman cabai membutuhkan air yang banyak adalah disaat pertumbuhan vegetatif, pembungaan dan pembuahan. Pada vegetatif kebutuhan air sebanyak $125 \mathrm{ml}$ air setiap harinya sedangkan pada masa pembungaan dan pembuahan 225 $\mathrm{ml}$ setiap hari. Rata-rata curah hujan yang baik untuk tanaman cabai antara 600-1.250 $\mathrm{mm} / \mathrm{tahun}$.

\section{Data curah hujan}

Data curah hujan diperoleh dari stasiun penakar curah hujan Balai Penyuluh Pertanian Perikananan dan Kehutanan Tangkiling, Palangka Raya. Hujan di Lokasi Pengkajian menunjukkan bahwa pada saat penanaman pada bulan Julicurah hujan sebesar $40 \mathrm{~mm}$, sedangkan pada bulan, Agustus, September, Oktober berturut-turut sebanyak $101 \mathrm{~mm}, 27 \mathrm{~mm}$ dan $109 \mathrm{~mm}$ sehingga harus dilakukan penyiraman untuk memenuhi kebutuhan air tanaman cabai. Seperti terlihat pada Gambar 1.

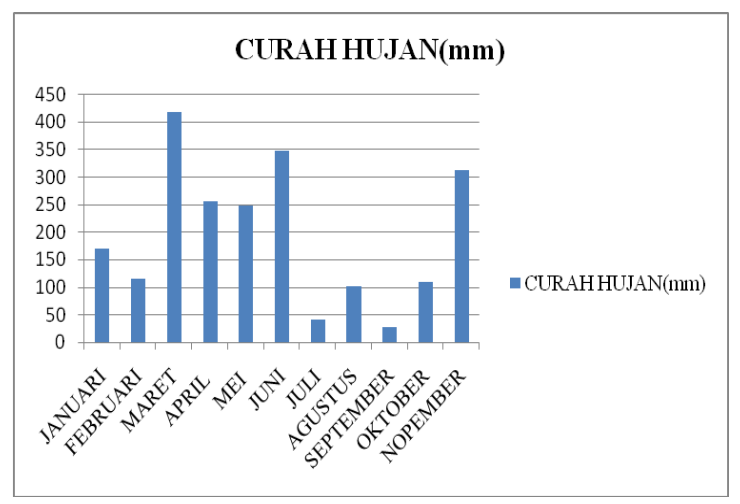

Gambar 1. Data curah hujan di lokasi pengkajian

Sedangkan hari hujan pada saat penanaman seperti pada Gambar 2 adalah 5 hari dalam satu bulan, sedangkan pada saat perawatan yaitu di Bulan Agustus, September dan Oktober hanya terdapat 8, 2 dan 6 hari hujan dalam sebulan. Dapat dikatakan selama penanaman, pemeliharaan dan hingga panen termasuk dalam musim kemarau. 


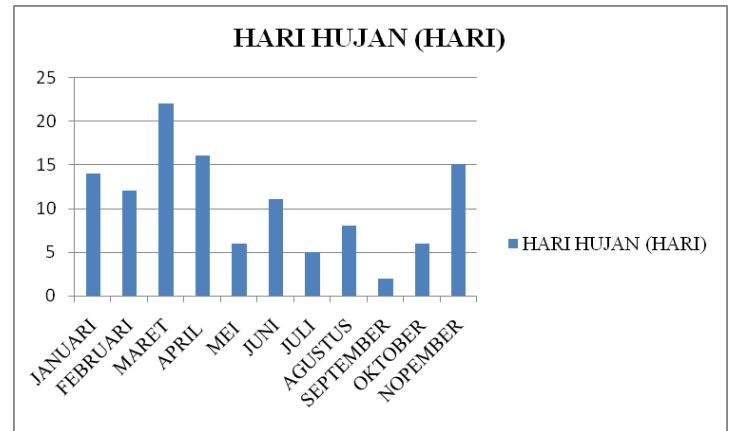

Gambar 2. Data harihujan di lokasipengkajian

Analisis kelayakan usaha tani cabai merah

Secara finansial, usaha budidaya cabai merah dilahan gambut dikatakan menguntungkan jika biaya yang dikeluarkan dapat ditutupi oleh nilai jual hasil produksi cabai yang dipanen. Analis usahatani cabai merah dilahan gambut dilakukan atas biaya tetap, sarana produksi dan tenaga kerja. Biaya tetap terdiri atas sewa lahan dan biaya penyusutan alat. Biaya sarana produksi terdiri atas biaya benih, pupuk, pestisida, ajir, mulsa dan tali rafia. Sedangkan biaya enaga kerja, semuanya diupahkan. Analisis biaya serta pendapatan disajikan pada tabel 1 .

Dari hasil analisis usaha tani cabai merah, diketahui total biaya per hektar yang dibutuhkan sebesarRp. 81,822,000. Biaya tersebut terbagi menjadi biaya sewa lahan sebesar Rp. 5,000,000 (6.11 \%), biaya penyusutan alat Rp. $380,000 \quad(0.46 \%)$, pengadaan benih sebesar Rp 1,600,000 (1.96\%), pengadaan kapur Rp. 4,000,000 $(4.89 \%)$, pengadaan pupuk kandang Rp. $15,000,000$ (18.33 \%), pengadaan pupuk kimia Rp. 10,000,000 (12.22 \%), pengadaan calcium boron Rp. 560,000 (0.68 \%), pengadaan pestisida Rp. 12,280,000 (15.01 $\%$ ), ajir Rp. 5,262,000 (6.43 \%), mulsa dan tali Rp 7,100,000 (8.68\%) dan biaya tenaga kerja sebesar Rp. 20,640,000 (25.23\%).

Dengan jumlah populasi per hektar 17,540 pohon diperoleh hasil produksi 16,743 $\mathrm{kg}$ atau setara dengan 954,6 gram/tanaman. Harga jual cabai merah pada saat panen senilai Rp. $28,800 / \mathrm{kg}$ sehingga diperoleh penerimaan sejumlah Rp. 482,198,400. Keuntungan yang didapatkan senilai Rp. 400,376,400 sehingga didapatkan $\mathrm{R} / \mathrm{C}$ ratio senilai 5.89. Sedangkan nilai $\mathrm{B} / \mathrm{C}$ diperoleh nilai 4.89. Dikarenakan nilai $\mathrm{R} / \mathrm{C}$ ratio dan $\mathrm{B} / \mathrm{C}$ ratio lebih dari 1 maka usahatani cabai merah di lahan gambut layak diusahakan dan menguntungkan.

Analisa Usahatani Cabai Merah di Lahan Gambut Palangka Raya pada Juni-Nopember 2014 (/ha/musim)

\begin{tabular}{lrrrr}
\hline \multicolumn{1}{c}{ URAIAN } & Volume & Satuan & $\begin{array}{c}\text { HargaSatuan } \\
(\mathbf{R p})\end{array}$ & Jumlah (Rp) \\
\hline BIAYA TETAP & & & & \\
1. Sewa lahan & 1 & Ha & $5,000,000$ & $5,000,000$ \\
2. Biaya Penyusutan alat & 1 & Paket & 380,000 & 380,000 \\
SARANA PRODUKSI & & & & \\
1. Benih & 16 & sachet & 100,000 & $1,600,000$ \\
2. Kapur Dolomit & 3 & ton & $1,000,000$ & $3,000,000$ \\
3. Kapur bangunan & 1 & ton & $1,000,000$ & $1,000,000$ \\
4. Pupuk Kandang & 20 & ton & 750,000 & $15,000,000$ \\
5. Pupuk kimia NPK 16:16:16 & 1 & ton & $10,000,000$ & $10,000,000$ \\
6. Calsium Boron & 14 & liter & 40,000 & 560,000 \\
7. Pestisida & 1 & paket & $12,280,000$ & $12,280,000$
\end{tabular}




\begin{tabular}{lrrrr}
\hline 8. Ajir & 17,540 & batang & 300 & $5,262,000$ \\
9. Mulsa & 10 & rool & 700,000 & $7,000,000$ \\
10. Tali Rafia & 4 & gulung & 25,000 & 100,000 \\
TENAGA KERJA & & & & \\
1. Persiapan Lahan & 80 & HOK & 60,000 & $4,800,000$ \\
2. Penanaman & 16 & HOK & 60,000 & 960,000 \\
3. Pemupukan & 80 & HOK & 60,000 & $4,800,000$ \\
4. Penyemprotan & 40 & HOK & 60,000 & $2,400,000$ \\
5. Panen & 128 & HOK & 60,000 & $7,680,000$ \\
TOTAL BIAYA & & & & $81,822,000$ \\
HASIL PRODUKSI(Kg) & & & & 16,743 \\
HARGA JUAL (Rp/Kg) & & & & $482,198,400$ \\
JUMLAH PENERIMAAN & & & & $400,376,400$ \\
JUMLAH KEUNTUNGAN & & & & 5.89 \\
R/C Ratio & & & & \\
B/C Ratio & & & & \\
\hline
\end{tabular}

Sumber: Analisis Data Primer (2014)

KESIMPULAN

Usahatani cabai merah di lahan gambut dengan penggunaan input benih varietas unggul, pengolahan tanah yang baik, perlakuan pemupukan dengan dosis pupuk kandang 20 t/ha, NPK 16:16:16 1 t/ha, dolomite 2 t/ha, kapur bangunan 1 t/ha, Kalcium boron 14 1/ha mampu mendapatkan hasil produksi cabai merah varietas pilar sejumlah $16,743 \mathrm{t} / \mathrm{ha}$ dengan populasi 17,540 tanaman/ha. Total keuntungan yang diperoleh sejumlah Rp. 400,376,400. Dari hasil kajian didapatkan bahwa usaha tani cabai merah dilahan gambut secara finansial layak diusahakan dengan nilai $\mathrm{R} / \mathrm{C}$ ratio 5.89 dan menguntungkan dengan nilai $\mathrm{B} / \mathrm{C}$ ratio 4.89 .

\section{UCAPAN TERIMA KASIH}

Terima kasih penulis ucapkan kepada Bank Indonesia Kantor Perwakila Palangka Raya dan Rudi Kuswanto yang telah mensupport kegiatan ini.

\section{DAFTAR PUSTAKA}

Anonim. 2010. Statistik Hortikultura

Kalimantan Tengah Tahun 2010.

Dinas Pertanian dan Peternakan Provinsi Kalimantan Tengah.

Palangka Raya. 88 hal. . 2012. Laporan Tahunan Balai

Perlindungan Tanaman Pangan dan Hortikultura Provinsi Kalimantan Tengah Tahun 2009. Balai Perlindungan Tanaman Pangan dan Hortikultura Provinsi Kalimantan Tengah. Palangka Raya.

Direktorat Perlindungan Tanaman Pangan. 2008. Teknologi Pengendalian Organisme Pengganggu Tumbuhan (OPT) Ramah Lingkungan. Direktorat Jenderal Tanaman Pangan. Jakarta.

Firmansyah, M.Anang dan Astri Anto. 2013. Teknologi Budidaya Bawang Merah Lahan Marjinal di Luar Musim. Palangka Raya : Kantor Perwakilan Bank Indonesia. 
Halim, A., Saul M.R., G. Soepardi.1988. Perbaikan Tanah Gambut Dengan Peningkatan Kejenuhan Basa Dalam BudidayaTanaman Kedelai (Makalah disajikan Dalam Kongres I Himpunan Gambut Indonesia dam Seminar Nasional Gambut I di Yogyakarta), Yogyakarta.

Hardjowigeno, S. 1993. Klasifikasi Tanah dan Pedogenesis. Jakarta : Akademika Pressindo.

Las, Irsal et al. 2011. Perubahan Iklim dan Pengelolaan Lahan gambut Berkelanjutan. Bogor : Balai besar Penelitian dan Pengembangan Sumber daya Lahan pertanian.

Lingga, Pinus dan Marsono. 2007. Petunjuk Penggunaan Pupuk.Jakarta : Penebar Swadaya.

Munawar, Ali. 2011. Kesuburan Tanah dan Nutrisi Tanaman. Bogor : IPB Press.

Noor, M. 2001. Pertanian Lahan Gambut Potensi dan Kendala. Yogyakarta : Kanisius.

Redaksi Trubus. 2012. Cabai My Potential Business. Depok : PT Trubus Swadaya.

Rostini, Neni. 2012. 9 Strategi Bertanam Cabai Bebas Hama dan Penyakit. Jakarta : Agro Media.
Sastrosupadi, Adji. 1999. Rancangan Percobaan Praktis Bidang Pertanian(Edisi Revisi). Yogyakarta : Kanisius.

Soekartawi. 1995. AnalisisUsahatani. Universitas Indonesia Press. Jakarta. , 2002. Ilmu Usahatani. Jakarta

Suryanto. 1994. Diktat Materi Kuliah Tanah dan Lingkungan. Penataran Alih Tahun Program Pasca Sarjana IlmuIlmu Pertanian UGM. Yogyakarta.

Soepardi, G. 1983. Sifat dan Ciri Tanah. Bogor: Fakultas PertanianIPB.

Soetarso,T.A dan W. Setiawati. 2010. Kajian Teknis dan Ekonomis Sistem Tanam Dua Varietas Cabai Merah di Dataran Tinggi. Jurnal Hortikultura 20(3): 284-298.

Sunaryono. 1992.Bertanam Cabai. Jakarta : Gramedia. 